PYRROLOPYRIMIDINE NUCLEOSIDES 19.1 A TOTAL SYNTHESIS OF THE NUCLEOSIDE ANTIBIOTIC CADEGUOMYCIN [2-AMINO-7-( $\beta-D-R I B O F U R A N O S Y L)-$ PYRROLO [ 2,3-d] PYRIMIDIN-4-ONE-5-CARBOXYLIC ACID]

vladimir G. Beylin, Andrew M. Kawasaki, Chin Shu Cheng, and Leroy B. Townsend* Department of Medicinal Chemistry, College of Pharmacy, and Department of Chemistry University of Michigan, Ann Arbor, Michigan 48109

Abstract. A total synthesis of 2-amino-7-(B-D-ribofuranosy1)pyrrolo[2,3-d]pyrimidin-4-one5-carboxylic acid has been accomplished and confirms the previous structural assignment for the nucleoside antibiotic cadeguomycin.

The isolation, characterization, and chemical synthesis $2-4$ of the pyrrolo[2,3-d]pyrimidine nucleoside antibiotics tubercidin, toyocamycin, and sangivamycin, as well as their biological and chemotherapeutic activity, ${ }^{2-5}$ created considerable interest in the synthesis of compounds related to this class of adenosine analogs. The isolation and characterization of nucleoside $Q^{6}$ and $Q^{*^{7}}$ from certain $t-\mathrm{RNA}^{\prime} \mathrm{s}$ prompted considerable interest in the synthesis as well as studies on the hiological and chemotherapeutic activity of various guanosine- like pyrrolo[2,3-d]pyrimidine nucleosides. ${ }^{8-11}$ Interest in the area of guanosine-like pyrrolo[2,3-d]pyrimidine nucleosides has been renewed by a recent report on the isolation and characterization of the new and novel nucleoside antibiotic cadeguomycin 12,13 as 2-amino-7-(B-D-ribofuranosy1)pyrrolo[2,3-d]pyrimidin-4-one-5-carboxylic acid (5). This antibiotic was reported ${ }^{13}$ to have inhibitory effects on transplantable animal tumors but no significant antimicrobial activity against bacteria and fungi. It has been assumed 12 that this nucleoside antibiotic possessed the structure $\underline{5}$ solely on the basis of physicochemical properties. We now wish to report a total synthesis of the nucleoside 2-amino-7-(B-D-ribofuranosyl)pyrrolo [2,3-d]pyrimidin-4-one-5-carboxylic acid (ㅁ, cadeguomycin).

We initiated two separate routes for the total synthesis of cadeguomycin, with each route being designed to ultimately afford the desired antibiotic. In the first route investigated, we envisaged the use of 2-amino-7-(B-D-ribofuranosyl)pyrrolo[2,3-d]-pyrimidin-4-one-5carboxamide (4) as the immediate precursor of cadeguomycin. The synthesis of this precursor (4) was accomplished from the nucleoside antibiotic toyocamycin via a seven step sequence. However, the low yield (148) from the last step, treatment of 2-amino-5-cyano-7-(B-Dribofuranosyl)pyrrolo[2,3-d]-pyrimidin-4-one ${ }^{8}$ (3) in concentrated ammonium hydroxide with hydrogen peroxide at $<20^{\circ}$, prompted us to investigate an alternate synthesis of 4 . $A$ successful alternative synthesis of 4 involved the conversion of 2-chloro-7-(B-D-ribofuranosyl)pyrrolo[2,3-d] pyrimidin-4-one-5-carboxamide ${ }^{14}$ (2), with liquid ammonia in a sealed steel reaction vessel $\left(100^{\circ}, 96 \mathrm{hrs}\right)$, into 4 in 868 yield, ${ }^{16} \mathrm{mp} 260.5-261.5^{\circ}$ (dec.., browning began $>228^{\circ} ;{ }_{H-N M R}^{1}\left(60 M H z\right.$, DMSO- $\left.{ }_{-6}\right):=10.95$ (br $\left.\mathrm{s}, 1 \mathrm{H}, \mathrm{N}_{3}-\mathrm{H}\right), 7.55(\mathrm{~s}, 1 \mathrm{H}$, $\mathrm{C}_{6}-\underline{\mathrm{H}}$ ), 9.54 and 7.10 (two br $\mathrm{s}, 2 \mathrm{II}, \mathrm{CONH}{ }_{2}$ ), 6.50 (br s, $2 \mathrm{H}$, $\mathrm{NH}_{2}$ ) $5.90\left(\mathrm{~d}, 1 \mathrm{H}, \mathrm{C}_{1},-\mathrm{H}\right.$, $\left.\mathrm{J}_{1,}, 2^{\prime}=6.4 \mathrm{~Hz}\right)$. The nucleoside 4 (15 mg) was then treated with $3 \mathrm{~N}$ HCl at $80^{\circ}$ for 44 hrs. The $\mathrm{pH}$ of the solution was adjusted to $\mathrm{pH} 8$ by the addition of dilute ammonium hydroxide 
solution. The water was removed by lyophilization and the resulting white solid was isolated by HPLC (Whatman Partisil oDS-3,0-208 MeOH/H $\mathrm{H}_{2} \mathrm{O}$ gradient, retention time $53 \mathrm{min.}$ ) in 78 yield. It was determined that this solid was identical to cadeguomycin (5) (See Table I). However, the low yield once again prompted us to investigate an alternate route for the preparation of cadeguomycin ( $\underline{5})$.

\section{IABLE I}<smiles>[R]c1cn([R18])c2nc(N)[nH]c(=O)c12</smiles><smiles>[R16]n1cc(C#N)c2c(=O)[nH]c(Cl)nc21</smiles>

\begin{tabular}{|c|c|c|c|c|}
\hline \multirow{2}{*}{$\mathbf{R}$} & \multicolumn{3}{|c|}{$\lambda \max , \operatorname{nm}(\xi)$} & \\
\hline & neutral & acid & base & $R_{f}$ Ref. \\
\hline $\mathrm{H}$ & $\begin{array}{l}260(15800)^{k} \\
280(11200)^{k}\end{array}$ & $262(11200)^{d}$ & $262(12700)^{e}$ & $0.43 \quad 11$ \\
\hline $\mathrm{CN}$ & & $\begin{array}{l}288(6850)^{d} \\
268(8450) \\
227(17350)\end{array}$ & $\begin{array}{l}286(7000)^{e} \\
268(6500) \\
226(20000)\end{array}$ & $0.57 \quad 8$ \\
\hline $\mathrm{CONH}_{2}$ & $\begin{array}{l}293(6800)^{b} \\
270(6800) \\
229(13700)\end{array}$ & $\begin{array}{l}295(4200)^{d} \\
245(4500)^{k} \\
234(7600)\end{array}$ & $\begin{array}{l}290(4600)^{e} \\
253(6200) \\
232(11300)\end{array}$ & 0.35 \\
\hline $\mathrm{COOH}$ & $\mathrm{h}$ & $\begin{array}{l}298(7607)^{\mathrm{f}} \\
272(6881) \\
232(19677)\end{array}$ & $268(9175)^{8}$ & 12 \\
\hline $\mathrm{COOH}$ & $\begin{array}{l}291(8251)^{c, j} \\
266(9314) \\
228(20375)\end{array}$ & $\begin{array}{l}299(8658)^{f} \\
272(7586) \\
232(22940)\end{array}$ & $\begin{array}{l}269(10497)^{8} \\
229(21451)^{8}\end{array}$ & 0.53 \\
\hline
\end{tabular}

Toyocamycin

1<smiles>NC(=O)c1cn([Pb])c2nc(Cl)[nH]c(=O)c12</smiles>

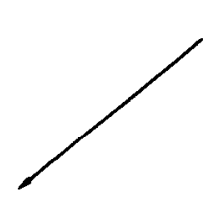<smiles>C[Te]</smiles><smiles>[10CH2]n1cc(C#N)c2c(=O)[nH]c(N)nc21</smiles>

$\underline{2}$<smiles>[R16]n1cc(C(N)=O)c2c(=O)[nH]c(N)nc21</smiles>

1

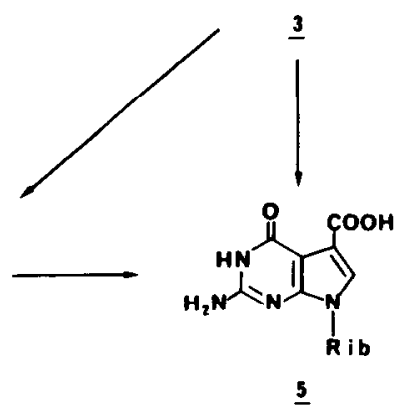

5

N NaOH; the same as in $0.1 \underline{\mathrm{N}} \mathrm{HC} 1 ;{ }^{\mathrm{i}} \mathrm{CH}_{3} \mathrm{CN}: \mathrm{H}_{2} \mathrm{O}$ :

$\mathrm{CH}_{3} \mathrm{COOH} / 90.5: 9.0: 0.5(\mathrm{v} / \mathrm{v} / \mathrm{v})$; $\mathrm{J}_{\text {the difference from values }}$ reported in reference 12 may be due to the difference in the pH of the water solutions; $k$ shoulder

$\mathbf{R} \mathbf{i b}=$<smiles>OC1[C@H](O)[C@@H](O)O[C@H]1O</smiles>

A solution of the nucleoside 3 (50 $\mathrm{mg} 0.163 \mathrm{mmol})$ in $3.5 \mathrm{~mL}$ of $6 \mathrm{~N}$ sodium hydroxide was heated at reflux for $3 \mathrm{hrs}$. Ethanol (40 $\mathrm{mL}$ ) was added to the chilled reaction mixture (ice bath) which effected a precipitation of the sodium salt of $\underline{5}$. Decantation of the reaction 
mixture furnished a thick syrup-like residue which was triturated with $40 \mathrm{~mL}$ of cold ethanol. The remaining solid was dissolved in water and the $\mathrm{pH}$ of the solution was adjusted to $\mathrm{pH} 4.0$ using an ion-exchange resin (Amberlite, IR-120, $\mathrm{H}^{+}$-form). A suspension of the nucleoside 5 was decanted from the resin, the resin was washed with cold water $(2 \times 10 \mathrm{~mL})$ and the 1 iquid removed by lyophilization. The resulting white solid ( $30 \mathrm{mg}$ ) was extracted with 20 and then 10 $\mathrm{mL}$ of hot methanol. The methanol extracts were evaporated to dryness in vacuo to yield $19.4 \mathrm{mg}$ (36.5\%) of 5 , which was dried over $\mathrm{P}_{2} \mathrm{O}_{5}$ at $80^{\circ} / 0.1 \mathrm{~mm} \mathrm{Hg}$ for $15 \mathrm{hrs;} \mathrm{mp} 305-308^{\circ}$ (dec.. browning began $>240^{\circ}$ ). A sample was recrystallized from a methanol:water(7:1/v:v) mixture and then dried under the same conditions as described above; mp 327-330 (dec., browing

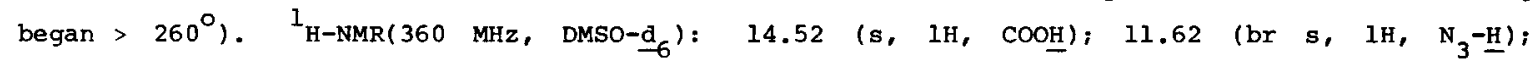
7.83 ( $\left.\mathrm{s}, 1 \mathrm{H}, \mathrm{C}_{6}-\underline{\mathrm{H}}\right) ; 6.79$ (br s, $2 \mathrm{H}, \mathrm{NH}_{2}$ ); 5.90 (d, $\left.1 \mathrm{H}, \mathrm{C}_{1},-\mathrm{H}, \mathrm{J}_{1}, 2^{\prime}=6.2 \mathrm{~Hz}\right) ; \mathrm{Ir}(\mathrm{KBr}$, $\left.\mathrm{cm}^{-1}\right): 3350,3440$ (OH, NH); 1650 (COOH) and essentially identical to the fingerprint region previously reported $^{12}$ for cadeguomycin. The cIMS $\left(\mathrm{CH}_{4}\right)$ of the hexasilylated ${ }^{15}$ nucleoside $\underline{5}$ showed $M$ and $M-15$ ions $(758$ and $743 \mathrm{~m} / \mathrm{z}$, respectively) which supported our structural assignment for the nucleoside 5 . Characteristic peaks ${ }^{15}$ of the base series calculated for this structure were observed in GC EIMS $(70$ e.v. $): B+188 ; B+131 ; B+128 ; B+116 ; B+100 ; B+74 ;$ $\mathrm{B}+58: \mathrm{B}+30 ; \mathrm{B}+13 ; \mathrm{B}+2 ; \mathrm{B}+1 ; \mathrm{B}(409 \mathrm{~m} / \mathrm{z}) ; \mathrm{B}-14 ;$ and peaks related to the sugar moiety were identical to those previously reported ${ }^{15}$; a peak for the molecular ion was not obtained under these conditions (EIMS).

The physicochemical data obtained for the nucleoside $\underline{5}$ proved to be very different from either the nucleoside $\underline{3}$ or the nucleoside $\underline{4}$, but essentially identical to the data reported 12 for the naturally occurring cadequomycin (Table 1). Therefore, this unequivocal synthesis of the nucleoside $\underline{5}$ and the comparison of physiochemical data for $\underline{5}$ and the reported values for cadeguomycin corroborates the previous structural assignment of cadeguomycin as 2-amino-7-(B-D-ribofuranosyl)pyrrolo[2,3-d] pyrimidin- 4-one-5-carboxylic acid.

The synthetic pathway we have developed, vide supra, for the total synthesis of the nucleoside antibiotic cadeguomycin can now be used to obtain a number of specific analogs of cadeguomycin for more extensive biological and chemotherapeutic evaluations.

\section{REFERENCES}

1. Pyrrolopyrimidine Nucleosides. 18. T. MARUYAMA, L.L. WOTRING, L.B. TOWNSEND, J. Med. Chem., 26, 25 (1983).

2. L.B. TOWNSEND, In "CRC Handbook of Biochemistry and Molecular Biology", 3rd ed.; Fasman, G. D., Ed.; Chemical Rubber Publishing Co.: Cleveland, OH, 271-401 (1975) and references cited therein.

3. R.J. SUHADOLNIK, "Nucleoside Antibiotics", Wiley: New York, (1970).

4. R.L. TOLMAN, R.K. ROBINS, L.B. TOWNSEND, J. Am. Chem. Soc., 91, 2102 (I969) and references cited therein.

5. R.J. SUHADOLNIK, "Nucleosides as Biological Probes", Wiley Interscience: New York, 158-169, (1979). 
6. M. KASAI, K. KUCHNO, S. NISHTMURA, Nucleic Acids Res., 2, 1931 (1975).

7. M. KASAI, K. NAKANISHI, R.D. MACFARLANE, D.F. TORGERSON, Z. OHASHI, J.A. MCCLOSKEY, H.J. GROSS, S. NISHIMURA, J. Am. Chem. SOC. 98, 5044 (1976).

8. C-S CHENG, B.C. HINSHAW, R.P. PANZICA, L.B. TOWNSEND, J. Am Chem. Soc. 98, 7870 (1976).

9. S. NOGUCHI, Z. YAMAIZUMI, O. TADAAKI, T. GOTO, Y. NISHIMURA, Y. HIROTA, S. NISHIMURA, Nucleic Acids Res. 5,4215 (1978).

10. F. SEELA, D. HASSELMANN, Chem. Ber. 114, 3395 (1981).

11. L.B. TOWNSEND, R.L. TOLMAN, R.K. ROBINS, G.H. MILNE, J. Heterocyclic Chem. 13, 1363 (1976).

12. R-T WU, T. OKABE, M. NAMIKOSHI, S. OKUDA, T. NISHIMURA, N. TANAKA, J. Antibiot. 35, 279 (1982).

13. N. TANAKA, R-T WU, T. OKABE, H. YAMASHITA, A. SHIMAZU, T. NISHIMURA, J. Antibiot. 35, 272 (1982).

14. C-S CHENG, Diss. Abstr. Int. B. 42, 1976 (1981).

15. H. PANG, K.H. SCHRAM, P.I. SMITH, S.P. GUPTA, L.B. TOWNSEND, J.A. MCCLOSKEY, J.Org. ChEm., 47, 3923 (1982).

16. Acceptable elemental analysis (C, H, N) have been obtained for all new compounds. Acknowledgement. This work was supported by Research Grant CA 28381 and in part by BRSG S07 RR 05571-16 from NIH. A. M. K. was the recipient of a university fellowship for minority students and a warner-Lambert medicinal chemistry graduate student fellowship.

(Received in USA 14 June 1983) 